\title{
Determination of Muslim Investor Behavior in Investing in Indonesian Capital Markets through Investor Intention
}

\author{
Dihin Septyanto, Yuswar Z. Basri, Tatik Mariyanti \\ willy.arafah@gmail.com
}

\begin{abstract}
This study aims to analyze the influence of attitude factor, subjective norm, behavior control, religiosity, religious events and influence of profit maximization factor to behavior through intention of Muslim investor to invest sharia product in capital market. The benefits of this research will be a basic model for issuers in developing syariah financial instruments as well as for regulators as a basis for developing or improving sharia products in the capital market significantly.
\end{abstract}

This research includes both explanatory and qualitative. The population in this study is Muslim investors who invest in sharia products in the stock market in Indonesia Stock Exchange (BEI). The sample in this research is as many as 253respondents of Muslim investors who invest in sharia products in the capital market. This research uses data analysis method using SmartPLS software version 2.0.m. PLS (Partial Least Square) is a variance-based structural equation analysis (SEM) that can simultaneously perform testing of measurement models as well as testing structural models.

The results of this study indicate that the factors of influence investor behavior are attitudes / morals, subjective norms / intention, behavior control, religiosity, religious events, and profit maximization. The result of coefficient of determination (R-Square) shows that the ability of Attitude / Abandonment variable, Subjective Norm / Intention, Behavioral Control, Religiosity, Religious Event, and profit maximization in explaining Intention of Investor to invest in syariah capital market is 0.8390 or $83.90 \%$, which means that the other variable opportunity in explaining variable Intensi investor investing in sharia capital market is $16.10 \%$. Variable intention in explaining the behavior of investors investing in sharia capital market has a coefficient of determination of 0.7106 or equal to $71.06 \%$. This means that other variable opportunities in explaining investor behavior invest in sharia capital market is equal to $28,94 \%$.

The results of this study can be taken into consideration for the parties concerned for the relevant parties such as the Indonesia Stock Exchange, Bapepam, MUI and other related institutions to further socialize investments in Islamic capital markets in accordance with Islamic teachings. This socialization can be through lecture materials of ustadz/ experts conducted in certain communities, such as campus, offices, and recitation.

Keywords: Sharia Capital Market, Attitude, Subjective Norm, Behavioral Control, Religiosity, Religious Event, Profit Maximization, Intention, Investor Behavior

\section{INTRODUCTION}

Islamic governments ranging from the Messenger of Allah until the period of Islamic rule did not recognize the sources of development financing from the Islamic Capital Market so that there was no Islamic Capital Market instrument. According to Achsien (2000) The first developer of the Sharia index and equity funds such as mutual funds are the United States, after The Amana Fund was launched by The North American Islamic Trust as the world's first equity fund in 1986, three years later the Dow Jones Index launched the Down Jones Islamic Market Index ( DJIM). Shariah Suvervisory board (SSB) from Dow Jones Islamic Market (DJIM) filters out halal shares based on business activities and financial ratios. Investment is one of the teachings and concepts of Islam that fulfill the process of tadrij and trichotomy of that knowledge. It can be proven that the concept of investment 
other than knowledge is also spiritual in nature because it uses sharia norms, as well as being the essence of a science and charity, therefore investment is highly recommended for every Muslim (Huda, Nasution, 2006).

Investment in Islam is part of muamalah activities, Islam views investment as a mandatory thing to do so that property becomes productive and can be more beneficial to others, and Islam strictly prohibits stockpiling of property. Islam as a rule of life (nidham al hayat) which regulates all aspects of human life, offers various ways and tips for living a life in accordance with the norms and rules of Allah SWT. Even in investing, Allah SWT and His Messenger provide instructions (postulates) and basic signs that should be followed by every faithful Muslim. Among the signs (Satrio, 2005 in Huda and Nasution, 2006) are as follows:

1. Free from the elements of usury

2. Avoid from gharar elements

3. Avoid elements of gambling (maisir)

4. Avoid from haram elements

5. Avoid from similar element (syubhat)

DSN-MUI has issued fatwa/provisions /rules related to the sharia financial industry including fatwas on the sharia capital market. Since November 2007, Bapepam \& LK has issued a List of Sharia Securities (DES) containing a list of Sharia shares in Indonesia. With the DES, the public will find it easier to find out what stocks are included in Sharia shares because DES is the only reference to the list of Sharia shares in Indonesia. One of the Sharia investments in the Indonesian capital market is known as the Jakarta Islamic Index (JII) which consists of only 30 Islamic stocks listed on the Indonesia Stock Exchange (IDX).

\section{Research Purposes}

The purpose of this study is:

1) Analyzing the influence of attitude factors on behavior through the intention of Muslim investors to invest in sharia products on the Indonesia Stock Exchange

2) Analyzing the influence of subjective norms on behavior through the intention of Muslim investors to invest in Islamic products on the Indonesia Stock Exchange

3) Analyzing the influence of behavioral control factors on behavior through the intention of Muslim investors to invest in sharia products on the Indonesia Stock Exchange

4) Analyzing the influence of religiosity factors on behavior through the intention of Muslim investors to invest in sharia products on the Indonesia Stock Exchange

5) Analyzing the effect of religious events on behavior through the intention of Muslim investors to invest in sharia products on the Indonesia Stock Exchange

6) Analyzing the effect of profit maximization factors on behavior through the intention of Muslim investors to invest in sharia products on the Indonesia Stock Exchange

\section{Benefits of Research}

This research is generally expected to provide benefits for:

1. The Islamic finance industry, especially sharia products in the capital market, can be developed significantly. This investor behavior model will be a basic model for issuers in developing Islamic financial instruments, especially Islamic investment products in the capital market 
2) Higher Education, as part of the development of university research, especially in the field of sharia products in the capital market

3) Researchers, as a contribution to thought through research in the field of Islamic product investment in the capital market

4) Regulators, as a basis for developing or enhancing sharia products in the capital market.

\section{LITERATURE REVIEW}

\section{Research Related to Investor Behavior}

Pitluck (2008) conducted a study entitled "Moral Behavior in Stock Markets: Islamic Finance and Socially Responsible Investment". The subject of money management is moral, ethical, religious or some other nonfinancial constraints known as Socially Responsible Investing (RSI). Investor behavior can be formed based on the religion believed by investors. Klein, Turk, and Weill in 2015 conducted a study entitled "How Religion Shapes Investor Behavior: Sukuk Issuances and Islamic Calendar Events". The aim of the research conducted by Klein et.al (2015) is to investigate how religious events in Islam can influence the stock market reaction to the issuance of sukuk relative to conventional bonds. Recent research on investor behavior in investing in the capital market is a study conducted by Warsame and Ireri (2016).The title of the research by Warsame and Ireri (2016) is “TPB matter in Sukuk investment decisions?" Research by Warsame and Ireri (2016) uses the TPB model to investigate the use of Sukuk in Qatar. Research by Warsame and Ireri (2016) revealed that attitudes have a significant and positive influence on behavioral intention to use Sukuk.

\section{Investation}

The definition of investment is based on the opinion of Tandelilin (2010). In addition to expecting the highest return from the investment, there are important things that must always be considered, namely how much risk must be borne from the investment. Generally the greater the risk, the greater the level of return on expectations.

\section{Principles of Islamic Economics in Investment}

Islamic principles regarding investment are: (Huda \& Nasution, 2008)

1. Not looking for rizki on unclean things, both in terms of substance and how to get it, and not use it for illegitimate matters.

2. Do not tyrannize and not be wronged

3. Justice in contributing to prosperity

4. Transactions are carried out on the basis of mutual pleasure

5. There is no element of riba, maysir (gambling / speculation), and gharar (obscurity or vague)

6. Hope to the pleasure of Allah, meaning that a particular form of investment is chosen in order to reach the pleasure of Allah (Sula, 2004)

\section{Consumer Behavior Theory}

Consumer behavior theory is the main basis of a behavioral theory from a microeconomic perspective. Engel et.al (1990) in Tjiptono (2008: 19) also revealed that consumer behavior is the actions of individuals who are directly involved in efforts to obtain, use, and determine products and services, including the decision-making process that precedes and follows these actions. Consumer behavior is shaped by several factors. Factors that 
influence consumer behavior are external factors that include culture, sub-culture, social status, demographics, family, referral groups. While internal factors, including preferences, learning, memory, motivation, personality, emotions, and attitudes. (Supranto and Limakrisna, 2007: 18)

\section{Islamic Consumer Behavior Theory}

\section{Consumer behavior in the perspective of Islam has limitations}

Limits and positive directives in consumer behavior are: (Najib, 2003)

1. Limitation in terms of nature and method, a Muslim must be sensitive to something that is forbidden by Islam. Consuming products that are clearly prohibited must be avoided, such as drinking khamr and eating pork. A Muslim must always consume something that is sure to bring benefits and benefits, so that it is far from secrecy. Because vanity is kemubadziran and it is forbidden in Islam.

2. Restrictions in terms of quantity or size of consumption, Islam forbids its people from being miserable, that is, too much restraint of the property given by Allah SWT to them. But God also does not want his people to spend their wealth excessively beyond reason (Quran Surah, 25: 67; 5: 87). Assets are a tool to achieve life's goals, if cultivated and used properly. (QS, 2.265)

\section{Understanding Religiosity}

That religiosity is an individual's experience and experience of the teachings of religion or beliefs held by him. Adisubroto (1987: 23) explains that religious humans are human beings whose overall mental structure is constantly directed to the creators of absolute value, satisfying and highest, namely God.

\section{Attitudes of Islamic Perspectives}

Bertens (2002:4) states that Ethics comes from the word ethos from the Greek language which means character, attitude and way of thinking. The formulation of morality arises as a medium that enables a good relationship between khaliq and virtue (Yaqub, 1993). Ethics is seen in terms of language, (morals) has a close relationship with the events of creation (khalqun), Creator (khaliq) and created (makhluq) because basically ethics or morals explain the relationship (Ali et al. 1990).

\section{Definition of Subjective Norms Islamic Perspective}

Subjective norms are determinants of intention / will (Refiana, 2002 in Santoso and Indarini, 2010).The reason for this subjective norm is found in the Hadith as follows:

From Amir al-Mu'minin, Abî Hafs Umar bin al-Khathab, he said: "I heard the Messenger of Allah say: Verily every act depends on its intentions and indeed everyone (will be rewarded) based on what he intended. So whoever migrates because of (wanting to get pleasure) Allah and His Messenger, then his migration to (the pleasure) of Allah and His Messenger, and who migrates because of the world he wants or because of the woman he wants to marry then his migration (will be of value) he intended."Narrated by two Imam of hadith; Abu Abdillah Muhammad ibn Ismail ibn Ibrahim ibn al-Mughirah ibn Bardizbah al-Bukhari, and Abul Husain Muslim bin alHajjaj ibn Muslim al-Qusyairi al-Naisaburi, in their two Sahih books which are the most authentic books ever written (HR Bukhori and Muslim No. 1907)

\section{Behavior Control}

The third component in intention theory is behavioral control or perceived behavioral control. Ajzen (2005) defines this perceived behavioral control as a reference that indicates the difficulty or ease that a person encounters in certain behavioral intentions. 
Determination of Muslim Investor Behavior in Investing in Indonesian Capital Markets through Investor Intention

\section{Religious Events}

The event discussed in this study is a religious event. Events related to religious activities.

The religious event that is often used in research on religious influence of events on the capital market is the event of Ramadan.

\section{Profit Maximization}

Islamic perspective related to efforts to obtain profits can be seen in the Word of God in the Qur'an Surat anNisa (4) verse 29:

"who believe, do not eat one another's wealth with vanity, except by the way of commerce which is like you. And do not kill yourself; indeed Allah is Merciful to you. "

\section{Variables}

Variables used in this study are attitudes, subjective norms, behavioral control, religiosity, religious events, and profit maximization on investor intentions, and investor behavior in Muslim investors in the DKI Jakarta region. Exogent variables are attitudes, subjective norms, behavioral control, religiosity, religious events, and profit maximization. Endogent variable is the behavior of Muslim investors.

\section{Hypothesis}

The hypothesis that will be developed is as follows:

Hypothesis 1: Attitudes influence the behavior of investors

Hypothesis 2: Subjective norms influence the behavior of investors

Hypothesis 3: Behavioral control influences investor behavior

Hypothesis 4: Religiosity affects the behavior of investors

Hypothesis 5: Religious events affect the behavior of investors

Hypothesis 6: Maximizing Profit affects the behavior of investors

\section{RESEARCH MeTHOdology}

This research is explanatory and quantitative, namely a study model to find and explain causal relationships between variables through hypothesis testing that uses a quantitative approach and will be analyzed qualitatively and quantitatively in order to better explain the causality relationship between variables through hypothesis testing and variable analysis - the research variable. By testing the influence of variables relating to attitudes, subjective norms, behavioral control, religiosity, religious events, and profit maximization on the intention and behavior of Muslim investors in investing in the sharia capital market, namely the Indonesia Stock Exchange and located in the Jakarta area. This study was analyzed with inferential statistics using the SPSS version 15.0 program, and SmartPLS version 2.0 which was intended to analyze the sample data that would be generalized to the population. The unit of analysis of this research is Muslim investors who invest in sharia products in the Indonesia Stock Exchange, as many as 250 respondents.

\section{Validity Test and Reliability Test}

Validity test used in this research instrument uses Pearson Product Moment Correlation (r) Statistics, which are measured for attitude variables, subjective norms, behavioral control, religiosity, religious events, and profit maximization on investor intense, and investor behavior using SPSS 15.0 Software. Reliability testing aims to determine the consistency of measurements made with existing instruments. The high and low reliability is 
Determination of Muslim Investor Behavior in Investing in Indonesian Capital Markets through Investor Intention

empirically shown by a number called the reliability coefficient. The reliability coefficient calculation technique uses Alpha Cronbach reliability coefficient.

\section{Data Analysis Model}

Data analysis methods in this study are divided into two, namely:

\section{Descriptive Statistics and Inferential Statistics Analysis}

Descriptive analysis is empirical analysis in the description of information obtained to provide an overview / describe about an event (who / what, when, where, how, how much) collected in the study (Supranto, 2001). Inferential statistics, (inductive statistics or probability statistics), are statistical techniques used to analyze sample data and the results are applied to populations (Sugiyono, 2004).

\section{Structural Equation Analysis Model}

The first phase of the structural analysis model built in this study can be seen in the following graph:

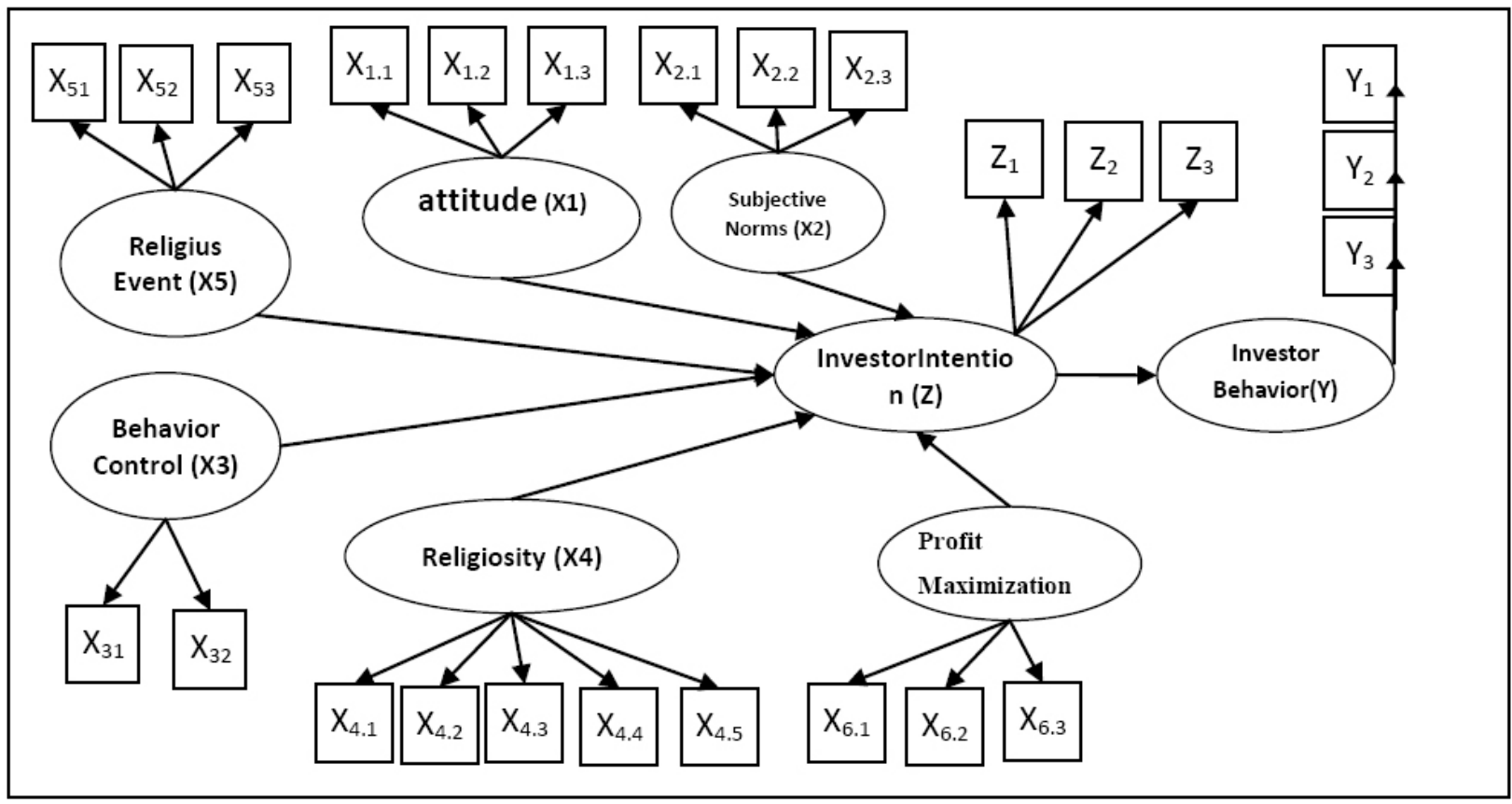

Figure. Flow Chart

Information :

X1.1 = Morals towards God, X1.2 = Morals towards yourself

X1.3 = Morals towards fellow human beings. X2.1 = intention of worship, X2.2 = intention of ta'at

X2.3 = intention qurban, X3.1 = internal factor, X3.2 = external factor,

$\mathrm{X} 4.1$ = dimension of belief, X4.2 = dimension of worship or practice of religion,

$\mathrm{X} 4.3$ = dimension of appreciation, $\mathrm{X} 4.4$ = dimension of practice,

X4.5 = dimension of religious knowledge, X5.1 = service, X5.2 = price, X5.3 = accessibility

$\mathrm{Z1}$ = personal factor, $\mathrm{Z2}$ = social factor, Z3 = Information

$\mathrm{Y} 1$ = principle of morality, $\mathrm{Y} 2$ = principle of generosity, $\mathrm{Y} 3$ = principle of simplicity

American Research Journal of Business and Management 


\section{Hypothesis testing}

According to Hartono (2008) in Hartono and Abdillah (2009) explains that a measure of the significance of the support hypothesis can be used in comparison of T-table and T-statistics values. If the T-statistic is higher than the T-table value, it means that the hypothesis is supported or accepted. In this study for a 95 percent confidence level (95 percent alpha), the T-table value for one-tailed hypothesis is> 1.66488. The PLS (Partial Least Square) analysis used in this study was carried out using the SmartPLS version 2.0.m3 program.

\section{RESEARCH RESULTS AND ANALYSIS}

\section{Descriptive of Research Data}

\section{Instrument Validity and Reliability Test}

The results of the instrument trial described earlier, show that all instruments of the variables in this study are valid and reliable. Valid and reliable instruments can collect valid and reliable research data, so the results of the research analysis are significant.

\section{Respondent Demographic Data}

Instrument testing was conducted on 30 respondents, after showing valid and reliable results, the instrument was used to collect 253 research data. Answers from as many as 253 respondents were analyzed in this study. A total of 253 investor respondents in this study, as many as 150 people or $59 \%$ were male. Respondents who are female are 103 people or $41 \%$. This shows that as many as 253 respondents in this study were not dominant based on sex.

Descriptive statistical analysis results show that respondents have ages between 25 to less than 35 years, which are 117 people or $46 \%$. A total of 74 respondents or as much as $29 \%$ had the age between 20 to less than 25 years, some aged between 34 to less than 50 years as many as 50 people or by $20 \%$. The oldest age is more than 50 years, which is 13 people or $5 \%$. This shows that the majority of respondents in this study are less than 50 years old, is a productive age to become an investor.

Most of the last education respondents reached the level of Bachelor or S1 as many as 158 people or by $63 \%$. For S2 level there are 32 people or 13\%. Respondents who have a Diploma level also have the same number of as many as 32 people or by $13 \%$, with the latest education up to the high school level of 29 people or $11 \%$. Only 1 respondent was educated to the level of S3 and up to junior high school level. The respondents last educational background illustrates the perception of diverse respondents also about investor behavior based on knowledge received by respondents from the respondents' last education.

Respondents in this study know the sharia capital market products mostly come from co-workers as many as 131 people or by $52 \%$. Many know the sharia capital market products from mass media, which is as many as 70 people or by $28 \%$. Sources of information about the sharia capital market from references or books are also one form of media that is used by respondents as many as 43 people or by $17 \%$, as many as 3 people get information from your own investors. The results of this descriptive statistical analysis show that the media of co-workers, mass media and books are the most widely accepted sources of investors regarding Islamic capital market products.

The results of the descriptive statistical analysis show that most respondents invest in Islamic products between 1 year to less than 3 years, namely 153 people or by $60 \%$. Respondents who have invested in sharia products between 3 years and less than 5 years are also many, namely 79 people or $31 \%$. Investors in this study were respondents who also had invested in Islamic products in the capital market for more than 5 years. 
Determination of Muslim Investor Behavior in Investing in Indonesian Capital Markets through Investor Intention

\section{Hypothesis Testing Results}

\section{Test Validity with Outer Loadings}

Validity test is used to test the unidimensionality of each construct. Test the validity of this model using the value of outer loadings (measurement model). The indicator loading factor value which is greater or equal to 0.5 can be said to be valid. The following section shows the results of the validity test. Overall Validity Test Attitude Variables, Subjective Norms, Behavioral Control, Religiosity, Event Religious, Maximizing Profit, Intention, and Behavior.

Figure below shows the results of validity tests for Attitude / Morals, Subjective / Intentional Norms, Behavioral Control, Religiosity, Religious Events, Profit Maximization, Intention, and Investor Behavior. Validity test results show that all indicator loading factor values are $>0.5$. Indicators explaining the variables of attitude / morality, subjective / intention norms, behavioral control, religiosity, religious events, profit maximization, intentions and investor behavior have a Loading factor value $>0.5$, that these indicators are valid to explain variables in this research.

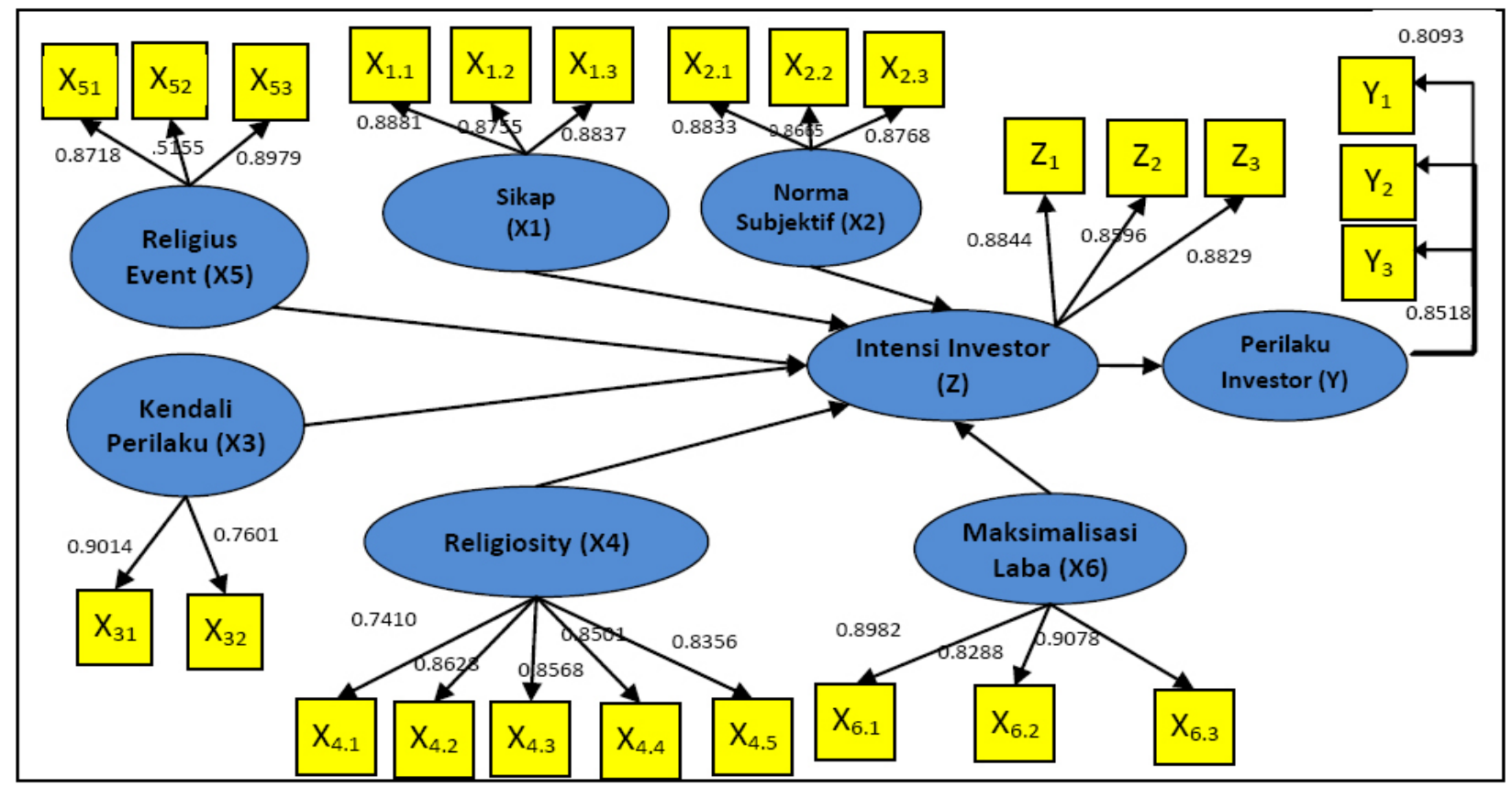

Source: Smart PLS Data Results, 2018

\section{Composite Reliability}

Data reliability testing is done with composite reliability. Chin (1998) says that "The unimensionality of the block of variables may be assessed by using composite reliability (should be> 0.7 )", that the level of reliability where composite reliability values are more than 0,7 .

Results: Composite Reliability

\begin{tabular}{|l|l|}
\hline Variable & Composite Reliability \\
\hline Attitude/Akhlak & 0,91 \\
\hline Norm Subjective & 0,76 \\
\hline Behavior Control & 0,70 \\
\hline
\end{tabular}


Determination of Muslim Investor Behavior in Investing in Indonesian Capital Markets through Investor Intention

\begin{tabular}{|l|l|}
\hline Religiosity & 0,70 \\
\hline Religius Event & 0,61 \\
\hline Profit Maximization & 0,77 \\
\hline Intention & 0,77 \\
\hline Profit Maximization & 0,72 \\
\hline
\end{tabular}

Source: Smart PLS Data Results, 2018

The value of composite reliability of all the variables in table 4.1 above shows that not all variables in this study have composite reliability values above 0.7 . One variable in this study has a composite reliability value of 0.61 smaller than 0.7 , which is a religious event variable. The reliability test results of this model mean that religious event variables are less reliable to be part of a model of measuring behavior of investors who invest in Islamic products in the capital market. Research variables have a high level of reliability based on composite reliability values greater and equal to 0.7 . Overall the variables in this study are reliable and can be used to test hypotheses.

\section{Cross Loadings}

The next stage of SEM model analysis using Smart PLS is to see the correlation between variables. Ghozali (2006) states that Cross Loadings aims to test data quality, where the correlation value of each variable with the indicator must be greater than the variable correlation with indicators of other variables.

Table. Cross Loadings Results

\begin{tabular}{|l|l|l|l|l|l|l|l|l|}
\hline Indikator & \multicolumn{1}{|c|}{$\mathrm{X} 1$} & \multicolumn{1}{|c}{$\mathrm{X} 2$} & $\mathrm{X} 3$ & $\mathrm{X} 4$ & $\mathrm{X} 5$ & $\mathrm{X} 6$ & $\mathrm{Z}$ & $\mathrm{Y}$ \\
\hline X11 & $\mathbf{0 , 8 8 8 1}$ & 0,7159 & 0,6073 & 0,6542 & 0,6194 & 0,6881 & 0,7080 & 0,6076 \\
\hline X12 & $\mathbf{0 , 8 7 5 5}$ & 0,6798 & 0,6471 & 0,6545 & 0,5810 & 0,7071 & 0,6860 & 0,7074 \\
\hline X13 & $\mathbf{0 , 8 8 3 7}$ & 0,6964 & 0,6246 & 0,6775 & 0,5738 & 0,7294 & 0,6822 & 0,6352 \\
\hline X21 & 0,7034 & $\mathbf{0 , 8 8 3 3}$ & 0,6630 & 0,7184 & 0,6649 & 0,7413 & 0,7843 & 0,6948 \\
\hline X22 & 0,6404 & $\mathbf{0 , 8 6 6 5}$ & 0,6420 & 0,6889 & 0,6338 & 0,7387 & 0,7341 & 0,7064 \\
\hline X23 & 0,7309 & $\mathbf{0 , 8 7 6 8}$ & 0,6679 & 0,7541 & 0,6604 & 0,7676 & 0,7551 & 0,7449 \\
\hline X31 & 0,6936 & 0,7633 & $\mathbf{0 , 9 0 1 4}$ & 0,7149 & 0,6208 & 0,7545 & 0,7775 & 0,7214 \\
\hline X32 & 0,4581 & 0,4417 & $\mathbf{0 , 7 6 0 1}$ & 0,5276 & 0,4785 & 0,4812 & 0,5180 & 0,4770 \\
\hline X41 & 0,4816 & 0,5242 & 0,5125 & $\mathbf{0 , 7 4 1 0}$ & 0,4993 & 0,5327 & 0,4807 & 0,4978 \\
\hline X42 & 0,6540 & 0,7157 & 0,6430 & $\mathbf{0 , 8 6 2 8}$ & 0,6232 & 0,6972 & 0,6924 & 0,6668 \\
\hline X43 & 0,6306 & 0,6620 & 0,6069 & $\mathbf{0 , 8 5 6 8}$ & 0,6033 & 0,6339 & 0,6281 & 0,5972 \\
\hline X44 & 0,6173 & 0,7244 & 0,6567 & $\mathbf{0 , 8 5 0 1}$ & 0,6653 & 0,6809 & 0,7203 & 0,6786 \\
\hline X45 & 0,6943 & 0,7465 & 0,6938 & $\mathbf{0 , 8 3 5 6}$ & 0,6693 & 0,7848 & 0,7883 & 0,7694 \\
\hline X51 & 0,6323 & 0,6813 & 0,5985 & 0,6278 & $\mathbf{0 , 8 7 1 8}$ & 0,6727 & 0,6908 & 0,6679 \\
\hline X52 & 0,2556 & 0,2893 & 0,3143 & 0,3813 & $\mathbf{0 , 5 1 5 5}$ & 0,3421 & 0,2991 & 0,3307 \\
\hline X53 & 0,5935 & 0,6800 & 0,5956 & 0,6905 & $\mathbf{0 , 8 9 7 9}$ & 0,7069 & 0,7104 & 0,7265 \\
\hline X61 & 0,7516 & 0,8214 & 0,6877 & 0,7551 & 0,7111 & $\mathbf{0 , 8 9 8 2}$ & 0,7960 & 0,7555 \\
\hline X62 & 0,6152 & 0,6416 & 0,5957 & 0,6259 & 0,6605 & $\mathbf{0 , 8 2 8 8}$ & 0,6921 & 0,7104 \\
\hline X63 & 0,7405 & 0,7824 & 0,7243 & 0,7550 & 0,6514 & $\mathbf{0 , 9 0 7 8}$ & 0,7863 & 0,7523 \\
\hline Z1 & 0,6912 & 0,7995 & 0,7325 & 0,7599 & 0,6673 & 0,7887 & $\mathbf{0 , 8 8 4 4}$ & 0,7504 \\
\hline
\end{tabular}


Determination of Muslim Investor Behavior in Investing in Indonesian Capital Markets through Investor Intention

\begin{tabular}{|l|l|l|l|l|l|l|l|l|}
\hline \hline Z2 & 0,7086 & 0,7464 & 0,6516 & 0,6772 & 0,6953 & 0,7437 & $\mathbf{0 , 8 5 9 6}$ & 0,7549 \\
\hline Z3 & 0,6598 & 0,7269 & 0,7099 & 0,6958 & 0,6555 & 0,7367 & $\mathbf{0 , 8 8 2 9}$ & 0,7078 \\
\hline Y1 & 0,5122 & 0,5762 & 0,5444 & 0,5907 & 0,5740 & 0,6172 & 0,6229 & $\mathbf{0 , 8 0 9 3}$ \\
\hline Y2 & 0,6809 & 0,7449 & 0,6787 & 0,7100 & 0,7024 & 0,7739 & 0,7745 & $\mathbf{0 , 8 7 5 3}$ \\
\hline Y3 & 0,6595 & 0,7361 & 0,6394 & 0,6848 & 0,6727 & 0,7312 & 0,7299 & $\mathbf{0 , 8 5 1 8}$ \\
\hline
\end{tabular}

Source: Smart PLS Data Results, 2018

Table shows that the correlation value of the indicator against the variable is always greater than the cross loadings of the other variables in a row. The value of cross loading gives the conclusion that the research data is fit and meets the criteria to be used to test the hypothesis.

\section{Hypothesis testing}

Testing the hypothesis in this study uses inner weights (structural models) which are processed with PLS.

Table. Result for Inner Weight

\begin{tabular}{|c|c|c|c|c|}
\hline & $\begin{array}{l}\text { Original Sample } \\
\text { Estimate }\end{array}$ & $\begin{array}{c}\text { Mean of } \\
\text { Subsamples }\end{array}$ & $\begin{array}{l}\text { Standard } \\
\text { Deviation }\end{array}$ & T-Statistic \\
\hline X11<- Attitude /Akhlak & 0.8881 & 0.8879 & 0.0254 & 39.9172 \\
\hline X12<- Attitude /Akhlak & 0.8755 & 0.8751 & 0.0254 & 34.4425 \\
\hline $\mathrm{X} 13<-$ Attitude/Akhlak & 0.8837 & 0.8799 & 0.0281 & 31.4946 \\
\hline X21<- Norm Subjective & 0.8833 & 0.8797 & 0.0236 & 37.4035 \\
\hline X22<- Norm Subjective & 0.8665 & 0.8603 & 0.0250 & 34.6454 \\
\hline X23<- Norm Subjective & 0.8768 & 0.8760 & 0.0229 & 38.2675 \\
\hline X31<-Behavior Control & 0.9014 & 0.9021 & 0.0156 & 57.7281 \\
\hline X32<-Behavior Control & 0.7601 & 0.7576 & 0.0621 & 12.2331 \\
\hline X41 <- Religiosity & 0.7410 & 0.7389 & 0.0552 & 13.4218 \\
\hline X42<- Religiosity & 0.8628 & 0.8580 & 0.0268 & 32.2273 \\
\hline X43<- Religiosity & 0.8568 & 0.8546 & 0.0276 & 31.0049 \\
\hline X44 <- Religiosity & 0.8501 & 0.8453 & 0.0362 & 23.4712 \\
\hline X45 <- Religiosity & 0.8356 & 0.8347 & 0.0245 & 34.0370 \\
\hline X51 <- Religius Event & 0.8718 & 0.8689 & 0.0273 & 31.8788 \\
\hline X52 <- Religius Event & 0.5155 & 0.5138 & 0.1219 & 4.2286 \\
\hline X53 <- Religius Event & 0.8979 & 0.8967 & 0.0230 & 38.9787 \\
\hline X61<-Profit Maximization & 0.8982 & 0.8963 & 0.0204 & 44.0029 \\
\hline X62<-Profit Maximization & 0.8288 & 0.8289 & 0.0347 & 23.8604 \\
\hline X63<-Profit Maximization & 0.9078 & 0.9065 & 0.0178 & 51.0242 \\
\hline Y1 <- Behavior (Y) & 0.8093 & 0.8037 & 0.0469 & 17.2647 \\
\hline Y2 <- Behavior(Y) & 0.8753 & 0.8762 & 0.0262 & 33.3892 \\
\hline Y3 <- Behavior $(\mathrm{Y})$ & 0.8518 & 0.8496 & 0.0364 & 23.3766 \\
\hline $\mathrm{Z} 1<-$ Intention $(\mathrm{Z})$ & 0.8844 & 0.8841 & 0.0223 & 39.6912 \\
\hline $\mathrm{Z} 2<-$ Intention $(\mathrm{Z})$ & 0.8596 & 0.8595 & 0.0266 & 32.3241 \\
\hline
\end{tabular}


Determination of Muslim Investor Behavior in Investing in Indonesian Capital Markets through Investor Intention

\begin{tabular}{|l|l|l|l|c|}
\hline Z3 <- Intention (Z) & 0.8829 & 0.8827 & 0.0207 & 42.5598 \\
\hline Intention -> Behavior & 0.8430 & 0.8412 & 0.0280 & 30.1273 \\
\hline Profit Maximization ->Intention & 0.2498 & 0.2417 & 0.1172 & 2.1307 \\
\hline Subjektif Norm ->Intention & 0.2973 & 0.2894 & 0.1005 & 2.9850 \\
\hline Behavior Control ->Intention & 0.1953 & 0.2000 & 0.0779 & 2.5057 \\
\hline Religiosity ->Intention & 0.0677 & 0.0738 & 0.0962 & 0.7036 \\
\hline Attitude ->Intention & 0.0778 & 0.0849 & 0.0777 & 1.0012 \\
\hline Religius Event -> Intention & 0.1221 & 0.1227 & 0.0835 & 1.4623 \\
\hline
\end{tabular}

Source: Smart PLS Data Results, 2018

\section{Determination Coefficient}

The results of the coefficient of determination (R-Square) indicate that the ability of the variable Attitude/ Morals, Subjective Norm/ Intentions, Behavioral Control, Religiosity, Religious Event and Profit Maximization in explaining the intention of investors to invest in Islamic products in the capital market is 0.8390 or $83.90 \%$, which means that the opportunities for other variables in explaining the variables Investors' intention to invest in Islamic products in the capital market is $16.10 \%$. Intention variables in explaining the behavior of investors investing in sharia products in the capital market have a determination coefficient of 0.7106 or $71.06 \%$. This means that the opportunity for other variables in explaining the behavior of investors investing in Islamic products in the capital market is $28.94 \%$.

\section{Discussion of Research Results}

The results showed that the variables of subjective norms, behavioral control and profit maximization directly affected the intention of investors to invest in Islamic products in the capital market. Whereas attitude, religiosity and religious events variables do not directly affect the intention of investors to invest in sharia products in the capital market, but indirectly affect the behavior of investors in investing in sharia products in the capital market.

Subjective norm variables that significantly influence investor intentions and behaviors in investing in sharia products in the capital market are in line with the research conducted by Pitluck (2008) and contrary to the results of the research by Tahir and Brimble (2011). Tahir and Brimble (2011) stated that investors are more rational than the value of religion. The results of this study indicate that the Subjective Norm or Intention in the perspective of Islam can significantly influence a person's intention and behavior variables. So, the results of this study are in accordance with the Qur'an and the Hadith that everything can happen depending on the intention or subjective norm of each person in deciding something.

Profit maximization directly affects investor intentions to invest in sharia products in the capital market, the results of this study are in line with Jamaludin (2013) León and Pfeifer (2013), Jagongo and Mutswenje (2014). This indicates that Muslim investors in this study are still in the rational category. The insignificance of religiosity and religious events is strengthened by the research of Jamaludin (2013), Tahir and Brimble (2011) and Warsame and Ireri (2016), in contrast to the research of Klein et.al (2015) on Sukuk products.

The religious event variable in this study is Ramadan worship activities. Seyyed et al. (2005) in Klein et.al (2015) studied the volatility of stock returns on the Saudi Arabian stock market during 1985-2000 and found that market volatility was lower during the month of Ramadan. Some research results show that during the month of Ramadan investment transactions in the capital market experienced a decline. The results of this study also 
show the same thing, that investors in this study do not have a significant influence between Ramadan activities and investor interest to invest in the Islamic capital market or Islamic products.

\section{Conclusions, Managerial Implications And Suggestions}

\section{Conclusions}

The results of this study can be summarized as follows:

1. The attitude / moral factors in this study can influence the behavior of investors through the variable intention of Muslim investors to invest sharia products on the Indonesia Stock Exchange significantly.

2. The subjective norm factor in this study can influence behavior through the intention of Muslim investors to invest in Islamic products on the Indonesia Stock Exchange.

3. Behavioral control factors in this study can influence behavior through the intention of Muslim investors to invest in Islamic products on the Indonesia Stock Exchange.

4. Religiosity factor in this study can influence behavior through the intention of Muslim investors to invest in sharia products on the Indonesia Stock Exchange.

5. Factors of religious agendas (religious events) in this study can influence behavior through the intention of Muslim investors to invest in Islamic products on the Indonesia Stock Exchange.

6. The profit maximization factor in this study can influence behavior through the intention of Muslim investors to invest in sharia products on the Indonesia Stock Exchange.

\section{Managerial Implications}

Based on the results of this study the managerial implications of proposed are as follows:

1. Variable Attitudes / Morals owned by investors can increase and decrease investment in the Islamic capital market. Strengthening attitudes / morals not only morals towards God, but also the morality towards oneself and fellow human beings is very important in order to improve the behavior of investors to invest in the Islamic capital market. This is the information provided by the capital market on the Indonesia Stock Exchange.

2. The Religiosity variable in this study also has a pretty good value, but it has not been formed the intention of investors to invest in the capital market or invest in the Islamic capital market. This increase in religiosity is very important in increasing investment in the Islamic capital market. The realization of a high level of religiosity by socializing investments in Islamic capital markets according to Islamic teachings. This socialization can be done through the lectures of the religious teachers in the recitation groups.

3. The religious variable of the event also has a high value of investor perception, but it does not significantly affect the intention of investors to invest in the Islamic capital market. The results of this study indicate the need for special attention by the companies and supervisors of the Islamic capital market institutions during religious events such as in the month of Ramadan. The number of attractive products with attractive prices, more satisfying services and the ease of investors to invest in the month of Ramadan, will increase the intention and behavior of investors to invest in the Islamic capital market.

4. The average value for the variable attitude, religiosity and religious event that is less than 0.2 indicates that the respondents in this study have a low attitude, religiosity, and religious event. The distribution of data that is not too diffuse because the standard deviation is close to 0 , also shows that the research in the future, it needs diversity of respondents in giving answers to attitudes, religiosity and religious events, so that the responses of respondents are more diverse. 


\section{Suggestion}

1. The next researcher is recommended to use a wider sample, such as all investors who transact in the capital market, so that the results of the research will be broader and can be applied more generally

2. Subsequent researchers are also expected to develop better mechanisms for forming investor intentions and behaviors by adding other variables that can influence so as to produce a good model and can explain the intentions and behavior of investors to invest in the Islamic capital market in the Indonesia Stock Exchange with very large value.

3. This socialization related to sharia products in the Indonesian capital market needs to be encouraged and can be done through the lectures of the religious teachers in recitation groups and through existing social media.

\section{REFERENCES}

Al Qur'an

Abdalloh, Irwan, 2016, http://akucintakeuangansyariah.com/23881/prospek-pasar-modal-syariah-indonesialuar-biasa/

Abdul Rahman Shaleh dan Muhbib Abdul Wahab., 2004, Psikologi Suatu Pengantar Dalam Presprktif Islam, (Jakarta: Prenada media.

Ahyadi AA., 2001, Psikologi Agama, Kepribadian Muslim, Bandung: Sinar Baru.

Ajzen, I, 2005, Attitudes, Personality, and Behavior, Edisi kedua, New York: Open University Press.

Ajzen, I., Fishbein, M. 1975. Belief, Attitude, Intention, and Behavior : An Introduction to Theory and Research. $1^{\text {st }}$ ed. Addison-Wesley Pub. Co., Reading, Mass

Al Munawar, Said Agil Husin, 2005, Al-Qur'an Membangun Tradisi Kesalehan Hakiki, Ciputat : PT. Ciputat Press

Al-Ghazali, Muhammad, 1993, Akhlak Seorang Muslim, Semarang : Wicaksana

Ancok, D., Suroso, N.F., 2008, Psikologi Islam,Yogyakarta: Pustaka Belajar.

Andjani, A. Sari., 1991, Efektivitas Teknik Kontrol Diri Pada Pengendalian Kemarahan, Jurnal Psikologi, Fakultas Psikologi Universitas Gadjah Mada, Yogyakarta

Ash Shiddieqy, Teungku Muhammad Hasbi, 2002, Mutiara Hadits I, Semarang : Pustaka Rizky Putra

Assael, H. 1992. ConsumerBehavior and Marketing Action. New York: PWS-KENT Publishing Company

Azwar, Saifuddin.2002.Pengantar Psikologi Intelegensi. Yogyakarta: Pustaka Pelajar

Bialkowski, J., Etebari, A., Wisniewski, T., 2012. Fast Profits: Investor Sentiment and Stock Returns during Ramadan. Journal of Banking and Finance 36, 835-845.

Beit-Hallahmy, B., Argyle, 1997, The Psichology of Religious, Behaviour, Belief and Experiemce, First Edition, London : Routledge

Bentler, P.M, 1995, EQS Structural Equations Program Manual, Encino, CA : Multivariate Software

Bertens, K, 2002, Etika, Jakarta : PT. Gramedia Pustaka Utama

Best, Roger J., 2000, Market-Based Management: Strategies for Growing Customer Value and Profitabiliy, PrenticeHall, New Jersey 
Determination of Muslim Investor Behavior in Investing in Indonesian Capital Markets through Investor Intention

Byrne, B.M, 2001, Structural Equation Modelling With AMOS : Basic Concepts, Application, and Programming. Mahwah, NJ : Lawrence Erlbaum

Chang, M.K. 1998. Predicting Unethical Behavior: A Comparison of the Theory of Reasoned Action and the Theory of Planned Behavior. Journal of Business Ethics Volume 17, Issue 16, pp 1825-1834 doi:10.1023/ A:1005721401993

Chin, W.W. 1995. Partial Least Squareis to LISREL as Principal Componwnta Analysis is to cammon Factor Analysis. Technology Studies, 2:315-319

Choudhury, M.A., 2013, Handbook of Tawhidi Methodology: Economics, Finance, Society, and Science. Jakarta : Trisakti University Press

Cooper, Donald R. \& Schindler, Pamela S. 2006, Bussines Research Methods, 9th edition. McGraw-Hill International Edition.

Cravens, David W and Nigel F. Piercy, 2007, Stategic Marketing. McGraw-Hill, Boston

Eagly, A. H., \& Chaiken, S. 1993. The psychology of attitudes. Fort Worth: Harcourt Brace Jovanovich.

East, R, 1997. Consumer Behavior: Advances and Applications in Marketing. London: Prentice Hall.

Ekbis.sindonews.com, 2016, Daftar Efek Syariah Terbaru Cetak Rekor Jadi 345 Emiten, https://ekbis.sindonews. com/read/1158944/32/daftar-efek-syariah-terbaru-cetak-rekor-jadi-345-emiten-1480339542

Erfani, A. 2017. Low Fertility Intention In Tehran, Iran: The Role Of Attitudes, Norms And Perceived Behavioural Control. Journal of Biosocial Science, 49(3), 292-308. doi:10.1017/S0021932016000109

Ferdinand, Augusty. 2005. Structural Equation Modeling. Semarang: BP Undip.

Fishbein, M., \& Ajzen, I. 1975. Belief, Attitude, Intention, and Behavior: An Introduction to Theory and Research. Reading, MA: Addison-Wesley.

Ghozali, Imam., dan Fuad. 2008. Structural Equation Modelling Teori, Konsep, dan Aplikasi. Semarang: Badan Penerbit Universitas Diponegoro.

Glock J., Strak, R., 1968, American Piety : The Nature of Religious Commitment, University of Californai Press

Gray, B. J., dan Hooley, G. J. 2002. Thriving on turbulence.Journal of Market-Focussed Management, 2: 231-57

Hair, J. F., Black, W.C., Babin, B.J., Anderson, R.E., 2010, Multivariate Data Analysis (7th Edition), New Jersey : Parson Prentice Hall

Halim, Abdul,2005, Analisis Investasi, . Edisi Kedua. Jakarta , Salemba Empat.

Hamzah Ya'qub., 1993, Etika Islam, Bandung: Diponrgoro.

Hartono, Jogiyanto dan Abdillah, 2009, Konsep dan Aplikasi PLS, BPFE,Yogyakarta.

Hasyim, Muhammad Ali., 1995, Apakah Anda Berkepribadian Muslim ?, Jakarta : Gema Insani

Hawkins, D. 1998. Consumer Behavior: Building Marketing Strategy, (7th Edition). New York: McGraw-Hill.

Hogh, Michael, Graham Vaughan.2002. Social Physchology, Third Edition, Prentice Hall, United Kingdom

Huda, Nurul., Nasution, Mustafa Edwin, 2008, Investasi pada pasar modal syariah. Cet ke-2 .Jakarta:Kencana.

Huda, Nurul., 2006, Perilaku Konsumsi Islami [online], Tersedia : xa.yimg.com/kq/groups/2. (2 Juli 2015)

American Research Journal of Business and Management

Page 14 
Determination of Muslim Investor Behavior in Investing in Indonesian Capital Markets through Investor Intention

Izutsu, Toshihiko, 1993, Konsep-konsep Etika Religius Dalam Qur'an , Terjemahan Agus Fahri Husain, Yogyakarta: Tiara Wacana

Jaffar, M. A. and Musa, R.. (2013), Determinants of Attitude Towards Islamic Financing Among Halal-Certified Micro and SMEs : A Proposed Conceptual Framework, International Journal of Education and Research, 1 (8).

Jagongo, Ambrose., Mustwenje, Vincent S, 2014, A Survey of the Factors Influencing Investment Decisions: The Case of Individual Investors at the NSE, International Journal of Humanities and Social Science, Vol. 4 No. 4 [Special Issue - February 2014], page 92-102

Jamaludin, Nurasyikin, 2013, Religion and Individual Investment Choice Decision: The Case of Malaysia, International Journal of Business and Social Science, Vol. 4 No. 1; January 2013, Page 104-113

Jaworski, Bernard.,Kohli, Ajay K., Sahay, Arvind. 2000. Market Driven Versus Driving Market. Journal of the Academy of Marketing Science 28: 45-54

Karijin, B., Iris, V., Florence, B.B. and Wim, V. (2007), "Determinants of halal meat consumption in France”, British Food Journal, Vol. 109 No. 5, pp. 367-86.

Karim, Adiwarman Azwar. 2007. Ekonomi Makro Islami. Jakarta: Rajagrafindo Persada.

Karim, Adiwarman Azwar.2011. Bank Islam Analisis Fiqih dan Keuangan, edisi 4. Jakarta : PT. Rajawali Pers

Kertajaya, Hermawandan M Syakir Sula, 2006, Syariah Marketing, Mizan, Bandung

Klein, Paul-Olivier., Turk, Rima., Weill, Laurent, 2015, How Religion Shapes Investor Behavior: Sukuk Issuances and Islamic Calendar Events, http://febs2016malaga.com/wp-content/uploads/2016/06/38Howreligion-shapes.pdf. Page 1-25

Kotler, Philip and Garry Amstrong, 2006, Principles of Marketing.Milleniumdition, A Simon \&Schucer Company, Ebnglewood Cliff, Pretice Hall International, Inc, New Jersey

Kotler, Philip. 2000. Marketing management: Analysis, planning, implementation and control, Ninth Edition, Prentice Hall, Inc, Upper Saddle River, New Jersey

Koufaris, M., Hampton-Sosa, W., 2004, The Development of Initial Trust in An Online Company by New Customers, Information and Management, January, (41:3), pp : 377-397

León, Anja Köbrich., Pfeifer, Christian.2013, Religious Activity, Risk Taking Preferences, and Financial Behaviour: Empirical Evidence from German Survey Data. University of Lüneburg ,Working Paper Series in Economics, No. 269, www.leuphana.de/institute/ivwl/publikationen/working-papers.html. Page 1 - 28

Lee, Kaman. 2009. Gender differences in Hong Kong adolescent consumers' green purchasing behavior, Journal of Consumer Marketing, Vol. 26 Issue: 2, pp.87-96, https://doi.org/10.1108/07363760910940456

Loudon, David L and Albert J. Della Bitta, 2004, Consumer Behavior Concepts and Appications.Third Edition Singapore, MC Graw Hill Inc.

Malhotra, Naresh K., 1999. Marketing Research: An Applied Orientation, Third Edition, Prentice Hall International Inc, New Jersey

Manstead, A. S. R. and van Eekelen, S. A. M. 1998, Distinguishing Between Perceived Behavioral Control and Self-Efficacy in the Domain of Academic Achievement Intentions and Behaviors. Journal of Applied Social Psychology, 28: 1375-1392. doi:10.1111/j.1559-1816.1998.tb01682.x 
Determination of Muslim Investor Behavior in Investing in Indonesian Capital Markets through Investor Intention

Mannan, M.A. 1986.Islamic economics: Theory and practice. Cambridge : Hodder and Stroughton

Masy'ari, Anwar., 1990, Akhlak Al-Qur'an, Surabaya: Bina Ilmu

Muhammad, 2013, Maksimalisasi Laba Usaha: Perspektif Konvensional Dan Islam, At-Taradhi: Jurnal Studi Ekonomi, Vol 4, No. 1 (2013), http://dx.doi.org/10.18592/taradhi.v4i1.92

Nafik, Muhammad, 2009, Bursa Efek dan Investasi Syariah, Jakarta: Serambi Ilmu Semesta

Naumann, Earl; Giel, Kathleen. 1995.Customer Satisfaction Measurement and Management: using the voice of the customer. USA: International Thomson Publishing.

Otoritas Jasa Keuangan, 2016, www.ojk.go.id

Pawlak, Roman \& Malinauskas, Brenda .2008.The Use of the Theory of Planned Behavior to Assess Predictors of Intention to Eat Fruits Among 9th-Grade Students Attending Two Public High Schools in Eastern.Family and Consumer Sciences Research Journal, 37,16-26

Pitluck, Aaron Z, 2008, Moral Behavior in Stock Markets: Islamic finance and socially responsible investment, MPRA Paper No. 9477, posted 8. July 2008

Rahmawati, V., 2012, Intention To Purchase The Private Label Brand: The Roles Of Financial Risk Perception, Price, And Value Consciousness For Consumers Of Hypermarket In Surabaya, diakses 2 Juli 2015, http:// www.google.com.

Refiana, Laila.2002. Analisis Behavioral Intention : Kasus Pelaksanaan Hak Cipta Software Komputer, ( Jakarta : Penerbit Universitas Indonesia, 2002).

Salarzehi, Habibollah. Hamed, Armesh, Davoud, Nikbin. 2010. Waqf as a Social Entrepreneurship Model in Islam. International Journal of Business and Management Vol. 5, No. 7; July 2010

Schiffman, Leon G. and Lesli Lazar Kanuk, 2000, Consumer Behavior, 7th Edition, Prentice Hall Inc, Upper Saddle River, New Jersey.

Sekaran, U. 2003. Research Methods for Business : A Skill Building Approach .2 nd Edition, John Wiley and Son. New York.

Seow AN, Choong YO, Moorthy K, Chan LM. 2017, Intention to visit Malaysia for medical tourism using the antecedents of Theory of Planned Behaviour: A predictive model. Int J Tourism Res. 2017;19:383-393. https://doi.org/10.1002/jtr.2120

Seyyed, F., Abraham, A., and Al-Hajji, M. 2005. Seasonality in Stock Returns and Volatility: The Ramadan Effect. Research in International Business and Finance 19(3): 374-383.

Shah, S. M. Atiq Ur Rehman., Ahmed, Syed Nisar,2014, The Ramadan Effect on Stock Market, European Academic Research Vol. I, Issue 11/ February 2014. Page 4712 - 4720

Shih, Y.Y., Fang, K. 2004. The Use of A Decomposed Theory of Planned Behaviour to Study Internet Banking In Taiwan.Internet Research. Vol 14. No. 3. Pp. 213-223

Siddiqi, Muhammad Nejatullah. 1992. Teaching Public Finance In Islamic Perspective. Jeddah: Centre for Research in Islamic Economics King Abdulaziz University

Spreng, R.A.,MacKenzie, S.B.,Olshavsky, R.W.1996. A reexamination of the determinants of consumer satisfaction. Journal of Marketing, 60(3), 15 - 32.

Statistik Syariah, 2015, www.idx.co.id/MarketInformation/MarketIndex,

American Research Journal of Business and Management

Page 16 
Determination of Muslim Investor Behavior in Investing in Indonesian Capital Markets through Investor Intention

Sudarmiatin. 2009. Model Perilaku Konsumen dalam Perspektif Teori dan Empiris pada Jasa Pariwisata. Jurnal Ekonomi Bisnis, Tahun 14, No. 1. Maret 2009.(1-11)

Tahir, Imran., Brimble, Mark, 2011, Islamic investment behaviour, International Journal of Islamic and Middle Eastern Finance and Management, http://ssrn.com/abstract=1884000,

The Cockcroft Report.1982.Mathematics counts : Report of the Committee of Inquiry into the Teaching of Mathematics in Schools under the Chairmanship of Dr WH Cockcroft. London: Her Majesty's Stationery Office

Turk-Ariss, R., Rezvanian, R., Mehdian, S., 2011. Calendar Anomalies in the Gulf Cooperation Council Stock Markets. Emerging Markets Review 12, 293-307.

Warsame, Mohammed Hersi., Ireri, Edward Mugambi, 2016, Does the theory of planned behaviour (TPB) matter in Sukuk investment decisions?, Journal of Behavioral and Experimental Finance, Volume 12, December 2016, Pages 93-100

Zaenudin, A., Jamhari, Muhammad., 1998, Al-Islam, Jilid 2, Bandung : Pustaka Setia

Citation: Dihin Septyanto, Yuswar Z. Basri, Tatik Mariyanti. "Determination of Muslim Investor Behavior in Investing in Indonesian Capital Markets through Investor Intention" American Research Journal of Business and Management. 2018; 4(1): 1-17.

Copyright (c) 2018 Dihin Septyanto, Yuswar Z. Basri, Tatik Mariyanti. This is an open access article distributed under the Creative Commons Attribution License, which permits unrestricted use, distribution, and reproduction in any medium, provided the original work is properly cited.

American Research Journal of Business and Management

Page 17 